\title{
International Trade and Economic Growth in Nigeria
}

\author{
Esther O. Lawal ${ }^{1}$, Kamtochukwu Ezeuchenne ${ }^{2}$ \\ ${ }^{I}$ Depatment of Economics Babcock University, Ilisan - Remo, Ogun state, Nigeria \\ ${ }^{2}$ Graduate of Economics Babcock University, Ilisan - Remo, Ogun state, Nigeria
}

\begin{abstract}
Nigeria is a third world economy that places great emphasis on trade both domestic and international. This research work was aimed at determining the impact of international trade on the economic growth. Variables used in the measurement of international trade include: Imports, exports, balance of trade and trade openness while real gross domestic product was used as a measure for economic growth using periodic data from the years 1985-2015. The econometric tests employed made use of the Unit Root Test to establish stationarity of the variables, the Johansen Co-integration Test was used to determine the long run relationship between the variables while the Vector Error Correction Model (VECM) was used to analyze the data so as to determine the speed of adjustment of the variables. The result showed that there is a long run relationship between international trade and economic growth, import and trade openness are both insignificant in the short run but significant in the long run while export and balance of trade are significant in both the short and long run. The granger causality test showed that economic growth is independent of imports, exports and balance of trade but economic growth is unidirectional with trade openness. Therefore, the study recommends that government should increase its exploration of finished goods and reduce importation of finished goods to increase economic growth.
\end{abstract}

Key Words: international trade, economic growth, vector error correction model and granger causality.

\section{INTRODUCTION}

International trade is concerned with the relationship amongst nations in both the economic and financial sense;it plays a life-sustaining role in coordinating socio-economic performance and the possibilities for less developed countries (Adeleye J., Adeteye O. \& Adewuyi M. O. 2015). There is no country which has grown without the useful tool of trade, however the significance of international trade to economic growth relies a great deal on the conditions in which it works and the purpose it serves. The relevance of international trade originates from evidence that there is no country that can produce all commodities in terms of goods and services which its population requires for their utilization and consumption largely owing it to resources differences and constraints. It is therefore concluded that trade relationship suggests that countries need to export commodities in order to create revenue to be able to import those commodities which cannot be made domestically.

Nigeria has about thirty-seven solid minerals and a population estimate of over 173.6 million people as at 2013(world bank, United States Census Bureau), it possess one of the larger gas and oil reserves in the world, the economic achievement of the country is rather frail when compared to the emerging Asian countries such as China, brazil, India, south Korea, Indonesia, Malaysia and even Thailand. These nations had been far behind Nigeria or at par with Nigeria in terms of GDP per capital in 1970s, but in recent years they have been able to transform their economies to come out as key competitors on the global economic platform. In 1970, for instance, Nigeria had a GDP per capital of US $\$ 233.35$ and was ranked 88th in the world, when China was ranked 114th with a GDP per capital of US $\$ 111.82$ (Sanusi 2010). Today, China occupies a desirable position as the second largest economy after the United State of America, largely owing to her self-esteemed trade position. However, according to (Ehinomen and Damilola 2013), encouragement of economic growth is one of the major aims of foreign trade but recently, the case of the Nigerian economy has been quite different due to the instability of the economy as a result of high level of unemployment, unstable prices and adverse balance of payment etc. A major problem as to why the benefits of international trade cannot be found to have a positive effect on economic growth is the macroeconomic policy changes resulting from the trade which turned the country into an import reliant economy. More so, foreign trade has not contributed to economic growth because some of the goods imported into the country cause damage to the local industries by making their products seem inferior and therefore causing neglect, this thereby causes a decline in the rate of growth of output of such industries and this later affects the aggregate economy. This study, therefore seek to: i) determine the impact of international trade on Nigeria's economic growth; ii) determine the causal relationship between the international trade and economic growth in Nigeria; and iii) examine if there exist a long run relationship between international trade and economic growth in Nigeria. 


\section{LITERATURE REVIEW}

Several efforts have emerged to empirically evaluate the interaction between international trade and economic growth and the findings from these studies have been mixed. The existing empirical literature however does not provide clear evidence on relationship between international trade and economic growth. Many research works provide evidence that increasing trade internationally has a positive effect on GDP increase. On the other hand some studies report that it is difficult to find a clearly defined positive relationship or even that there is a negative or depressing relationship between international trade and growth.

\subsection{Evidence from developed countries}

Yanikkaya (2003) tested the relationship between trade openness and economic growth for more than 100 developed and developing countries using panel data from 1970 to 1997. The results show that openness to international trade does not have a clearly defined relationship with economic growth and the results further show that trade barriers were positively significantin association with economic growth, especially for developing countries and the findings of theoretical economic growth were not consistent.

Muhammad, Mohammad and Abdul (2012) examined the relationship between international trade, financial development and economic growth in Australia over the period of 1965-2010. Using The ARDL bounds testing approach. Their empirical evidence confirmed the long run relationship among the variables. The results showed that international trade, financial development and capital are the drivers of economic growth both in short run and long run. The feedback effect exists between international trade and economic growth. The results reported that the variables are cointegrated for long run relationship. Therefore exports, imports and trade openness have a positive impact on economic growth in Australia.

Balaguer , Florica and Ripollés (2012) investigated the relationship between foreign trade and economic growth in spain from (1900 -2012) using Results from Johansen's, Toda's and Yamamoto's methodologies. For the first six decades of the 20th century, a sub-period characterised by an inward oriented trade policy, they found that economic growth is somewhatindependent of foreign trade. But later on this outcome contradicts with findings for the sub-period after the Stabilisation and Liberalisation Plan in 1959, where a causal network among variables is supported. They found that both exports and energy imports have been a direct cause of the economic growth observed since the sixties.

Abughalia and Abusalem (2013) investigated the empirical analysis on the Libyan economy and its structural changes, with special reference to Libyan foreign trade during the last three decades (1980-2010). The analysis was conducted using descriptive analytical methods and statistical tools such as linear regression analysis. The study observed that the trade process between Libya and the EU has experienced some success, leading to more economic cooperation through bilateral relations, promoting the private sector to play its role in the trade process during the period of study. The gains from export were higher than the loss for import, where this situation has led to positive balance of payment.

Mongoe and mongale (2014) examined the relationship between foreign trade and economic growth in south Africa using co-integrated vector autoregression approach. The Empirical investigation exposes that inflation rate, export and exchange rates have a positive relation to GDP while import is negatively related to GDP.

\subsection{Evidence from developing countries}

Akanni (2007) studied the relationship between exports and economic growth in Indonesia using vector autoregressive (VAR) model. The estimates show the importance of both exports and economic growth to the economy of Indonesia. It was therefore concluded that exports and economic growth exhibits two-way cause structure, which is Export Leads to Growth in the long-run and Growth Leads to Export in the short-run. (Akanni, 2007) studiedthe impact of income generated from oil export on the economic growth in Iran, using the Cobb-Douglas production function. The study shows that in the economy of Iran there is progress in technology and they adjust comparatively fast to shocks in Iran. Oil exports contribute immensely to real income through real capital accumulation.

Akanni (2007) also studied whether oil exporting countries grow as their earnings on oil rents increases, using PC-GIVEID (Ordinary Least Squares Regression). The results of the study shows that there is a positive significant relationship between oil rents, investment and economic growth and it also proves that oil rents in most rich oil developing countries in Africa do not foster economic growth. Sarkar (2007) investigates the relationship between trade openness and economic growth. The cross-country panel data analysis was a sample 51 countries of the South during the years 1981-2002 and it was observed that for eleven rich and highly trade-dependent countries an increase in real growth is affiliated with an increase in trade share. Time series study of individual country experiences show that most of the countries covered in the sample including the East Asian countries observed no positive long-term relationship between trade openness and economic growth during 1961-2002. He finds that the experience of various regions and groups shows that only the middle 
income group shows a positive long-term relationship Sun, \&Heshmati, (2010), studied the effects of international trade on China's economic growth. using econometric and non-parametric techniques on 6 years data of 31 provinces in China from 2002 to 2007, their estimates revealed an increased participation in international trade helps stimulate rapid economic growth in china. Thus, international trade volume and china's trade structure on technological exports have a positive on China's regional productions

\subsection{Evidence from Nigeria}

Omoju and Adesanya (2012) examined the impact of trade on economic growth in Nigeria using data from1980 to 2010. Making use of the Ordinary Least Square (OLS) technique, the study showed that trade, exchange rate, government expenditure and foreign direct investment have a positive and significant impact on economic growth in Nigeria Saibu (2012) studied the direct and interactive effects of capital inflow, trade openness and economic growth using data from Nigeria over the period 1960 to 2011. The study engaged compositeindicators gotten from principal component analysis (PCA) in the Autoregressive Distributed Lag (ARDL) bound testing model. It found that the effect of capital inflow and trade on economic growth was statistically significant. The study also provided new facts in support of the modernization hypothesis that capital inflow and trade policy are dependent on each other and increasing growth in developing economies like Nigeria and that trade liberalization policies tend to enhance effectiveness of capital inflow and together they foster higher economic growth in Nigeria.

Nwosa (2012) studied the relative contribution of trade liberalization on trade tax revenue in Nigeria between 1970 and 2009 using a simplified regression estimate. Their estimates revealed that trade liberalization, labour force, gross domestic product and public debt impacted positively on trade tax revenue while exchange rate had a negative effect. They concluded that there is the need for adequate macroeconomic policy to improve trade liberalization in Nigeria. Ajayi and Atanda (2012) empirically examined the trade and capital flow channels of globalization on macroeconomic stability as proxy by real output growth rate in Nigeria between 1970 and 2009. They utilized an autoregressive model which indicated that the first lag of real output growth rate has a significant positive effect on real current growth rate, while the second autoregressive term is found to exert insignificant negative effect on current real output growth rate. Also, trade and capital flow dimensions were found to decline the macroeconomic stability level in Nigeria. In addition, the existence of cointegration was established amongst the series, while the short run analysis made use of the the error correction mechanism model which indicated that for any disequilibrium in the stability level in the short-run, the error correction term adjust $97.5 \%$ of this divergence to its long-run equilibrium.

Emeka, Ikpesu and Peter (2012) investigated the Macroeconomic impact of trade on Nigeria economic growth over the periods of 1970 to 2008 using a combination of bi-variate and multivariate models. The empirical examination points out that exports and Foreign Direct Investment inflows have positive and significant impact on economic growth in the Nigerian economy and that there should be a harmonization of export and fiscal policies, towards a greater shift of nonoil exports by the Nigerian government in order to achieve a desirable growth prospects of external trade.

Adelowokan and Maku (2013) empirically examined the effect of trade and financial investment openness on economic growth in Nigeria between 1960 and 2011. Findings from the reported dynamic regression model showed that trade openness and foreign investment exert both positive and negative effect on economic growth of the country respectively. In addition, the partial adjustment term, fiscal deficit, inflation and lending rate were found growth increasing. It was then proved that there is long-run relationship between trade openness, foreign investment, and economic growth in Nigeria.

Adenugba\&Dipo (2013) examined the performance of non-oil exports in the economic growth of Nigeria from 1981 to 2010. Their estimates revealed that non-oil exports have performed below expectations; therefore, giving reason to doubt the efficacy of the export promotion strategies that have been used and since implemented. They rightly indicated that the Nigerian economy is still far from shifting from crude oil exports and as such the crude oil sub-sector continues to be the single most important sector of the economy. Edoumiekumo\&Opukri (2013) empirically investigated the contributions of international trade (proxy with export and import values) to economic growth in Nigeria measured by real gross domestic product (RGDP). The Time-series data collected was for a period of 27years which was analyzed using Augmented Dickey-Fuller (ADF) test, Ordinary Least Square (OLS) statistical technique, Johansen co-integration test and Granger Causality test. The results showed that there is a positive relationship between the variables and also cointegration exists among the variables. In addition The Granger Causality test realized a uni-directional relationship showing that RGDP Granger cause export and also import Granger cause RGDP and export.

Olaifa, Subair and Biala (2013) empirically investigated the effect of trade liberalization on economic growth in Nigeria between 1970 and 2012 with a view to examining the possibility os a long term relationship existing between the two and also to account for the structural changes that may have occurred with the implementation of a free trade regime in 1986. Adopting the ordinary least squares in estimating the 
relationship, they find that there is a long run relationship between trade liberalization and economic growth in Nigeria. Strong evidence was also found to support structural changes that took place in 1986 with the use of free trade policy. However export was reported to have a negative relation to growth. The study concluded by recommending that an enabling environment that will engender further growth such as better infrastructural base, adequate financing support adherence to international best practice in export and sound institutional structure be put in place for sustainability. Arodoye and Iyoha (2014) studied the nexus between international trade and economic growth in Nigeria making use of quarterly time-series data for the period 1981 to 2010. The results indicated that there is a stable, long- run relationship between international trade and economic growth and they concluded that trade policies which are in favour of export expansion should be encouraged because exports are a driver of economic growth. Furthermore, an exchange rate policy which is favourable to export expansion and consistent with Nigeria's status as a small open economy should be encouraged.

\section{DATA AND METHODOLOGY}

This paper employs annual time series data on international trade and economic growth in Nigeria. This paper uses import, export, balance of trade and openness to trade as proxies for international trade and real gross domestic product (RGDP) as proxies for economic growth. The data were obtained from central bank

\subsection{Unit Root Test}

This studies the impact of international trade on economic growth in Nigeria uses time series data in the analysis. As a result of the time series data used, the variables cannot be trusted. Therefore the need for stationary data arises. The stationary data will be conducted using Augmented Dickey Fuller test (ADF). The parameters that will be used for the analysis are, LRGDP, LIMP, LEXP, LBOT and TROP. The unit root result is showed below.

Table 3.1 Tabular representation of ADF result

\begin{tabular}{|l|l|l|l|l|l|}
\hline Series & $\begin{array}{l}5 \% \\
\text { Critica } \\
\text { 1 Value }\end{array}$ & $\begin{array}{l}\text { ADF at first } \\
\text { difference } \\
\text { (Prob.) }\end{array}$ & $\begin{array}{l}\text { ADF Test at } \\
\text { first difference }\end{array}$ & $\begin{array}{l}\text { Equation } \\
\text { Specification }\end{array}$ & $\begin{array}{l}\text { Order of } \\
\text { integration }\end{array}$ \\
\hline LRGDP & -2.96 & 0.0375 & -3.10 & Intercept & I(1) \\
\hline LEXP & -2.97 & 0.0005 & -4.91 & Intercept & I(1) \\
\hline LIMP & -2.97 & 0.0002 & -5.29 & Intercept & I(1) \\
\hline LBOT & -2.97 & 0.0002 & -5.22 & Intercept & I(1) \\
\hline TROP & -2.98 & 0.0000 & -6.67 & Intercept & I $(1)$ \\
\hline
\end{tabular}

\section{Source: Authors computation using E-Views 9 (2017)}

From Augmented Dickey Fuller result above, all the variables are stationary at first difference at 5\% significant level. This shows that the variables are integrated at the same other 1(1). Johansen Co-integration test will follow to check for co-integration equation. Having concluded on the model based on the result above, lag length for the analysis will be selected.

\subsection{Optimal Lag Length Selection}

There are many lag length criteria in error correction model. There are Akaike Information Criterion, Schwarz Information Criteria, Hannan Quinn Information Criterion. A lag length with lowest value of any of the criteria will be considered as the optimum lag length and thus be selected. Below is lag length criteria table:

Table 3.2 Tabular Representation of the Lag Length Criteria

\begin{tabular}{|l|l|l|l|l|l|l|}
\hline Lag & Logl & LR & FPE & AIC & SIC & HQ \\
\hline 0 & -45.06 & NA & 2.17 & 3.45 & 3.69 & 3.52 \\
\hline 1 & 78.44 & 195.91 & 2.51 & -3.34 & $-.193^{*}$ & -2.89 \\
\hline 2 & -109.52 & $38.58^{*}$ & $1.95^{*}$ & $-3.76^{*}$ & -1.16 & $-2.95^{*}$ \\
\hline
\end{tabular}

Source: Authors computation using E-views 9.0(2017)

* indicates lag order selected by the criterion

LR: sequential modified LR test statistic (each test at 5\% level)

FPE: Final prediction error

AIC: Akaike information criterion

SC: Schwarz information criterion

HQ: -Hannan- Quinn information criterion 
Lag length selection is based on any criterion with lowest value. From the table above, SIC criterion chose lag1 as its best lag length, while LR, FPE, AIC and HQ criteria choose lag2 as best lag length. AIC has the lowest value at lag 2. Therefore, based on lag length criteria which states that the lower the value of any of the criteria, the better the model. Lag2 is the best lag length for this analysis and Akaike Information Criterion is the best criterion for this study. After the selection of the lag length, Johansen Co-integration model follows:

\subsection{Johansen Co-Integration Test}

This analysis is used to ascertain long run relationship between the explanatory variables and the dependent variable. The test comprises Trace statistics and Eigenvalue statistics. Decision will be drawn based on the number co-integration equation indicated by these statistics.

Table 3.3.1 Tabular Representation of the Johansen Co-integration test Based on Trace Statistic

\begin{tabular}{|l|l|l|l|l|}
\hline Hypothesized & & Trace & 0.05 & \\
\hline No. of CE(s) & Eigenvalue & Statistic & Critical Value & Prob.** \\
\hline None $*$ & 0.76 & 98.82 & 69.81 & 0.0001 \\
\hline At most $1 *$ & 0.61 & 58.77 & 47.85 & 0.0034 \\
\hline At most $2 *$ & 0.43 & 31.76 & 29.79 & 0.0293 \\
\hline At most $3 *$ & 0.34 & 15.91 & 15.49 & 0.0432 \\
\hline At most 4 & 0.13 & 3.98 & 3.84 & 0.0460 \\
\hline
\end{tabular}

Source: Authors computation using E-views 9.0 (2017).

Johansen co-integration test based on trace statistics compares trace statistics critical value and 0.05 critical value. Decision rule states: if trace statistics critical value is greater than 0.05 critical value, reject null hypothesis and accept alternative hypothesis. From the table above, Johansen co-integration result indicates five co-integration equation. I move forward Eigenvalue statistics.

Table 3.3.2 Tabular Representation of Johansen Co-integration test based on Eigenvalue

\begin{tabular}{|l|l|l|l|l|}
\hline Hypothesized & & Max-Eigen & 0.05 & \\
\hline No. of CE(s) & Eigenvalue & Statistic & Critical Value & Prob.** \\
\hline None $*$ & 0.76 & 40.04 & 33.87 & 0.0081 \\
\hline At most 1 & 0.61 & 27.01 & 27.58 & 0.0591 \\
\hline At most 2 & 0.43 & 15.84 & 21.13 & 0.2341 \\
\hline At most 3 & 0.34 & 11.93 & 14.26 & 0.1131 \\
\hline At most 4 & 0.13 & 3.98 & 3.84 & 0.0460 \\
\hline
\end{tabular}

Source: Authors computation using E-views9.0 (2017)

Thetable above represent Johansen co-integration test based on Max-Eigen statistics and the result denotes two co-integration equations. At 5\% significant level, Johansen co-integration equation based on trace and Max-Eigen value indicate co-integration equation and therefore, null hypothesis is rejected thus the acceptance of alternative hypothesis. This implies that there is a long run relationship between international trade and economic growth in Nigeria.

Vector error correction model follows so as to denote the short and long run coefficients.

$\mathrm{H}_{0}$ : there is no long run relationship between international trade and economic growth in Nigeria

$\mathrm{H}_{1}$ : there is a long run relationship between international trade and economic growth in Nigeria

\subsection{Vector Error Correction Model}

This test is carried out after the application of the Vector Auto-regressive Model (VAR) which is done to integrate the multi-variate time series.

Table 3.4.1 Tabular Representation of the Parameter to Determine the Short Run Relationship of Variables.

\begin{tabular}{|l|l|l|l|l|l|}
\hline Error Correction: & D(LRGDP) & D(LIMP) & D(LEXP) & D(LBOT) & D(TROP) \\
\hline CointEq1 1 & -0.0009 & 0.49 & -1.04 & -3.004 & -0.05 \\
\hline & $(0.03)$ & $(0.29)$ & $(0.41)$ & $(0.85)$ & $(0.09)$ \\
\hline & {$[-0.02]$} & {$[1.65]$} & {$[-2.53]$} & {$[-3.52]$} & {$[-0.56]$} \\
\hline
\end{tabular}

Source: Authors computation using E-views 9.0 (2017). 
Short run coefficients are showed in the table above. The first number is the coefficients of the variables and this is followed by standard error and t-statistics respectively. Under statistical criteria, the standard error and t-statistics will be used to interpret the result.

Table 3.4.2 Tabular Representation of the Vector Error Correction Model Results for Long Run Relationship.

\begin{tabular}{|l|l|l|l|}
\hline VARIABLE & CO-EFFICIENT & STANDARD ERROR & T-STATISTIC \\
\hline LIMP & -2.30 & 0.03 & -9.83 \\
\hline LEXP & 2.76 & 0.008 & -4.97 \\
\hline LBOT & -0.56 & 0.001 & 4.80 \\
\hline TROP & -3.30 & 0.001 & 4.76 \\
\hline LRGDP & 1.00 & & \\
\hline
\end{tabular}

Source: Authors computation using E-views 9 (2017)

The estimated long run model is shown as below

LRGDP $=2.30$ LIMP $-2.76 \mathrm{LEXP}+0.56 \mathrm{LBOT}+3.30 \mathrm{TROP}$

R-squared: 0.38

F-statistic: 4.08

From the result above, the interpretation comes after evaluating the result using $\mathrm{t}$-statistical criteria.

\subsection{Model Evaluation}

\subsubsection{T-Statistics Test}

This measures the partial significance of the independent variable on the dependent variable in the model. It determines whether the partial effects observed are statistically significant or not.

Table 3.5.1 Tabular Representation of the T-Statistics Test Results

\begin{tabular}{|l|l|l|l|l|l|}
\hline Variables & T-statistics & T-tabulated & Decision Rule & \\
\hline & Short run & Long run & & Short run & Long run \\
\hline LIMP & 1.65 & -5.97 & 2.06 & Insignificant & Significant \\
\hline LEXP & -2.53 & -5.24 & 2.06 & Significant & Significant \\
\hline LBOT & -3.52 & -3.19 & 2.06 & Significant & Significant \\
\hline TROP & -0.56 & -4.40 & 2.06 & Insignificant & Significant \\
\hline
\end{tabular}

Based on decision criteria, which states that if T-tab > T-cal null hypothesis will be accepted and alternative hypothesis will be rejected. This means that all the explanatory variables are statistically significant in the long run and only export and balance of trade is significant in the short run.

\subsubsection{F-statistics}

This measures the qualitative fit of the model. It is a statement of the extent to which the econometric model appears to be well specified. The higher the value of the F-statistics, the greater the overall significance of the estimated regression. If F-calculated is greater than the F-tabulated, the F-statistics shows a higher degree of association between the dependent variables.

Table 3.5.2 Tabular Representation of the F-Statistics Test Result

\begin{tabular}{|l|l|l|}
\hline F-CAL & F-TAB & DECISION CRITERIA \\
\hline 0.91 & 2.74 & Accept Null Hypothesis \\
\hline
\end{tabular}

Source: Authors computation using E-views9.0 (2017).

The test above is used to know how fit the model is and thus at 5\% significant level f-tabulated is greater than $\mathrm{f}$ calculated and therefore, the model is not statiscally significant.

\subsection{Pairwise Granger Causality Test}

\begin{tabular}{|l|l|l|l|}
\hline Null hypothesis & Observed & f-statistics & Prob. \\
\hline LIMP does not granger cause LRGDP & 29 & 0.84 & 0.44 \\
LRGDP does not granger cause LIMP & & 0.93 & 0.40 \\
\hline LEXP does not granger cause LRGDP & 29 & 1.29 & 0.29 \\
LRGDP does not granger cause EXP & & 0.05 & 0.94 \\
\hline LBOT does not granger cause LRGDP & 29 & 2.09 & 0.14 \\
LRGDP does not granger cause LBOT & & 1.06 & 0.35 \\
\hline
\end{tabular}




\begin{tabular}{|l|l|l|l|}
\hline TROP does not granger cause LRGDP & 29 & 1.60 & 0.22 \\
LRGDP does not granger cause TROP & & 14.04 & 0.005 \\
\hline LEXP does not granger cause LIMP & 29 & 4.24 & 0.02 \\
LIMP does not granger cause LEXP & & 1.49 & 0.24 \\
\hline LBOT does not granger cause LIMP & 29 & 3.21 & 0.05 \\
LIMP does not granger cause LBOT & & 4.90 & 0.01 \\
\hline TROP does not granger cause LIMP & 29 & 1.05 & 0.36 \\
LIMP does not granger cause TROP & & 10.39 & 0.00 \\
\hline LBOT does not granger cause LEXP & 29 & 7.21 & 0.00 \\
LEXP does not granger cause LBOT & & 9.74 & 0.00 \\
\hline TROP does not granger cause LEXP & 29 & 0.06 & 0.93 \\
LEXP does not granger cause TROP & & 8.97 & 0.00 \\
\hline TROP does not granger cause LBOT & 29 & 0.33 & 0.71 \\
LBOT does not granger cause TROP & & 7.91 & 0.00 \\
\hline
\end{tabular}

Source: Authors computation using E-views 9 (2017)

The result denotes that at $10 \%$ significant level, real gross domestic product causes trade openness; export causes import, balance of trade and trade openness. Furthermore balance of trade causes import, export and trade openness. Finally import causes balance of trade, and trade openness.

\subsection{Post-Estimation Test}

\subsubsection{Breusch-Godfrey Serial Correlation Lm Test}

This serial correlation test was used to check for the serial relationship between the variables. The null hypothesis stated absence of serial correlation but the alternative hypothesis states the presence of serial correlation. The prob.chi square if less than 5\% level of significance signifies the acceptance of the alternative and rejection of null hypothesis while the prob chi square greater than 5\% level of significance signifies the acceptance of the null hypothesis and rejection of the alternative hypothesis.

Table 3.7.1 Tabular Representation of Breusch-Godfrey Serial Correlation LM Test Result

\begin{tabular}{|l|l|l|}
\hline Lags & LM-Stat & Prob. \\
\hline 1 & 27.75 & 0.31 \\
2 & 2485 & 0.47 \\
\hline
\end{tabular}

Source: Authors computation using E-views 9.0 (2017)

The results above showed the prob. (chi-square) having a value of 0.47 which is greater than the $5 \%$ level of significance so therefore we accepted the null hypothesis which stated that there is no serial correlation

Table 3.7.2 Tabular representation of hetroscedasticity result

\begin{tabular}{|ll|lc|}
\hline f-statistics & 4.08 & Pro. F(4,26) & 0.01 \\
\hline Observed R-squared & 11.95 & Pro. Chi-squared(4) & 0.01 \\
\hline Scaled explained ss & 4.58 & Pro. Chi-squared(4) & 0.29 \\
\hline
\end{tabular}

Source: Authorscomputation using E-views 9 (2017)

\section{Hypothesis}

$\mathrm{H}_{0}$ : homoskedasticity

$\mathrm{H}_{1}$ : heteroskedasticity

At $5 \%$ significant level, probability level is 0.29 which is greater than 0.05 . Therefore, null hypothesis is accepted. This means that the variance for the residuals is uniform (homoscedasticity).

\subsubsection{Normality Test}

One of the assumptions of least square estimator is that the residuals are normally distributed; obeying well defined probability laws and also can bear any value which could be negative, positive or zero. So, this test will be used to know if the residuals are normally distributed. 


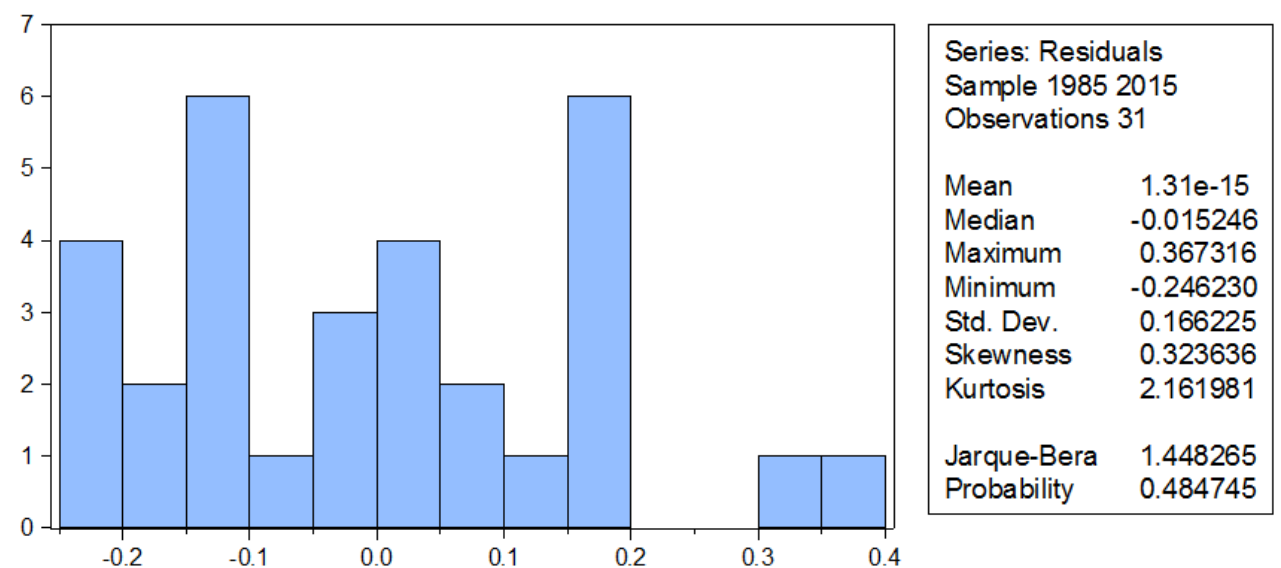

$\mathrm{H}_{\mathrm{o}}$ : The sample data are not significantly different than a normal population

$\mathrm{H}_{1}$ : The sample data are significantly different than a normal population.

Probabilities $>0.05$ accept the null hypothesis

Probabilities $<0.05$ reject the null hypothesis

From the result, the probability is 0.48 and this is greater than 0.05 at $5 \%$ significant level and therefore, the null hypothesis is accepted. This means that the residuals are normally distributed.

\section{DISCUSSION OF FINDINGS}

The analysis has established the fact that there exists a long run relationship between international trade and economic growth and this is denoted with the use of Johansen Co-integration test. Vector Error correction test carried out denotes that all the variables are statistically significant at 5\% significant level. All the explanatory variables have a negative relationship with real gross domestic product except export that indicates a positive relationship. The coefficients of the variables means that a unit increase in import will lead to a 2.3 units decrease in real gross domestic; a unit increase in export will lead to a 2.7 units increase in real gross domestic product; a unit increase in balance of trade will lead to 0.56 decrease in real gross domestic product and finally if government should increase open to trade, real gross domestic will decrease will by 3.3 units.

Granger causality test conducted indicates that at $10 \%$ significant level, real gross domestic product causes trade openness; export causes import, balance of trade and trade openness. Furthermore balance of trade causes import, export and trade openness. Finally import also causes balance of trade, and trade openness. The model is not statistically significant as f-tabulated is greater than f-calculated and also the value of $\mathrm{R}^{2}$ which is 0.38 indicates that $38 \%$ variation in the real gross domestic product is been accounted for by import, export, balance of trade and trade openness. The model also obeyed least square rules as there is no serial correlation in the model, the residuals are normally distributed and variance of the error term is uniform (homoscedasticity).

\section{CONCLUSION AND RECOMMENDATIONS}

Nigeria has profited from international trade over the years. However, the gains of trade could be greater if the economy and the production structures had been responsive and more adaptable to changes both internally and externally on the basis of internationaleconomic system. In a ever changing and highly competitive global environment, Nigeria needs to continually re-examine, revise and re-evaluate sourcesof strengths, weaknesses, opportunities and threats (SWOT analysis) in order to develop appropriate policy strategies, that can lead to maximum national benefits within the context of identified problems.

Based on the findings of the study, the following recommendations were made;

1. Since there is a positive long run relationship between exports and economic growth, The Nigerian Economy needs to concentrate on exportation of finished goods instead of the exportation of primary goods which in the long run we import as finished goods so as to improve domestic manufacturing industries, enhance productivity and increase employment which in the long run will increase economic growth and development and also increase exportation of finished goods.

2. There is a negative relationship between balance of trade and economic growth, so it is advised that the government should effectively reactivate the non-oil export sector to broaden the diversification of the economy's export sector and also increase employment opportunities which would in turn make balance of trade favorable.

3. Based on the findings of this study trade openness has a negative relationship with economic growth therefore, it is highly recommended that government should put in place quotas and increase tariff-barriers to prevent dumping which arises from trade openness. 
4. The findings of this study prove that there is a negative relationship between imports and economic growth so it is recommended that Public policies should be made to encourage adequate and successful management of innovation instead of adopting the exact knowledge from already known technological possibilities. This would lead to high level of technological endowment which will lead to high level of production of finished goods which would in turn reduce importation of finished goods.

\section{REFERENCES}

[1]. Abughalia and Abusalem (2013): Libyan Foreign Trade: A Time Series Analysis World Review of Business Research. 3(2): $25-42$

[2]. Adenugba, A. A. \& Dipo, S. O. (2013). Non-Oil Exports in the Economic Growth of Nigeria: A Study of Agricultural and Mineral Resources. Journal of Educational and Social Research, .3 (2): 403-418

[3]. Adelowokan and Maku (2013):Trade Openness, Foreign Investment and Economic Growth in Nigeria: A Long-Run Analysis,European Journal of Globalization and Development Research, 7(1)

[4]. Ajaji, S. I. (2003) Globalization and Africa. Journal of Africa Economics, 12, 120-150.

[5]. Akanni, O.P. (2007). Oil Wealth and Economic Growth in Oil Exporting Countries, AERC Research paper 170.

[6]. Arodoye and Iyoha(2014).Foreign Trade-Economic Growth Nexus:Evidence from Nigeria, CBN Journal of applied Statistics , 5(1)

[7]. Balaguer , Florica and Ripollés (2012):Foreign Trade and Economic Growth in Spain (1900-2008). The Role of Energy Imports USAEE Working Paper, 14-190

[8]. Granger, C. W. J. (1969) Investigating Causal Relations by Econometric Models and Cross- Spectral Methods. Econometrica, 37(3):422- 438.

[9]. Ehinomen, C. and Damilola D. (2013). Impact of Trade Openness on the Output Growth in the Nigerian Economy, British Journal of Economics, Management \& Trade, 4(5):754-767.

[10]. Edoumiekumo, S.G. \& Opukri, C.O. (2013). Economic Growth Factor in Nigeria: The Role of Global Trade. American Journal of Humanities and Social Sciences, 1(2): 51-55

[11]. Nwosa, P. I., Saibu M. O. \& Fakunle, O. O. (2012). The Effect of Trade Liberalization on Trade Tax Revenue in Nigeria. African Economic and Business Review, 10(2)

[12]. Mohammed, Muhammed and Abdul(2012):Financial Development, International Trade and Economic Growth in Australia:New Evidence from Multivariate Framework Analysis Online at https://mpra.ub.unimuenchen.de/42023/

[13]. Mongoe and mongale (2014):The Impact of International Trade on Economic Growth in South Africa: An Econometrics Analysis, Mediterranean Journal of Social SciencesDOI: 10.5901/mjss.2014.v5n14p60

[14]. Sarkar, P. (2007) “Trade Openness and Growth: is There Any Link?” Journal of International Trade and Political Economics 2 (1): 28-47

[15]. Sanusi L . S. (2010). Banks in Nigeria and National Economic Development; A Critical review, seminar on becoming an economic driver while applying banking regulation, CIBN, Lagos.

[16]. Sun, P. \& Heshmati, A. (2012). International Trade and its Effect on Economic Growth in China. IZA Discussion Paper No. 5151.

[17]. Olaifa, Subair and Biala (2013):Trade Liberalization and economic growth in Nigeria: a cointegration analysis, Journal of business, Economics and Finance.2 (3)

[18]. Omoju, O. \& Adesanya, O. (2012). Does Trade Promote Growth in Developing Countries? Empirical Evidence from Nigeria. International Journal of Development and Sustainability, 1(3), 743-753

[19]. WorldBank. (2010). Nigeria Trade Brief. World Trade Indicators 2009/1 0: Country Trade Briefs. Washington, DC: World Bank. http://www.worldbank.org/wti.

[20]. Yanikaya, H. (2003). Trade openness and economic growth: A Cross country empirical investigation. Journal of Development Economics 7(2), 57 - 89. 